Cifle International Journal of Industrial and Business Management (ISSN:2572-8423)

\title{
P2P lending industry in China
}

\section{Hang Yin}

\begin{abstract}
A judgmental sampling method is used to analyze the business models existing in China's P2P lending market. To achieve ${ }^{*}$ Correspondence to Author: this goal, this research selects the top 100 platforms based on Hang Yin outstanding loan amount to find out their business processes. After observing these platforms' official websites, this research divides all business models into three categories with the asset side, platform side, and liability side. At the asset side, $78 \%$ of sample platforms implement business of guaranteed loans, $59 \%$ offer risk reserve service on credit loans, $14 \%$ provide pure credit loans, and $6 \%$ supply insurance loans. There are also $13 \%$ E-mail: aigirl92@163.com of sample platforms refer to the transfer of creditor rights from other financial institutions. For the platform side, P2P lending businesses are presented by the time order of before lending, during lending, and after lending. And at the liability side, there are individual or institutional investors. In the last, this research uses the qualitative method to identify risks come along with How to cite this article:

Hang Yin. P2P lending industry in China. International Journal of Industrial and Business Management, 2017; $1: 4$. corresponding business models. These risks are mainly caused by P2P lending stakeholders' willingness or abilities. Among all the risks, platform side risks are most prominent.
\end{abstract}

\section{Keywords:}

P2P lending industry, China 
A judgmental sampling method is used to analyze the business models existing in China's P2P lending market. To achieve this goal, this research selects the top 100 platforms based on outstanding loan amount to find out their business processes. After observing these platforms' official websites, this research divides all business models into three categories with the asset side, platform side, and liability side. At the asset side, $78 \%$ of sample platforms implement business of guaranteed loans, $59 \%$ offer risk reserve service on credit loans, $14 \%$ provide pure credit loans, and $6 \%$ supply insurance loans. There are also $13 \%$ of sample platforms refer to the transfer of creditor rights from other financial institutions. For the platform side, P2P lending businesses are presented by the time order of before lending, during lending, and after lending. And at the liability side, there are individual or institutional investors. In the last, this research uses the qualitative method to identify risks come along with corresponding business models. These risks are mainly caused by P2P lending stakeholders' willingness or abilities. Among all the risks, platform side risks are most prominent.

\section{Narrow and broad sense of P2P lending}

Peer-to-peer lending allows borrowers with financing demand and lenders with the idle cash match each other through online platforms, promoting the allocation of capital. According to the differences between identities of borrowers or lenders, P2P lending is divided into narrow sense P2P and broad sense P2P.

\section{Narrow sense P2P lending}

It can also be called person-to-person lending in the narrow sense of P2P lending. In this narrow field, both borrowers and lenders are natural persons (Slattery, 2013). The borrowing purpose is mainly for personal consumption or individual operation, and the borrowing amount is relatively small.

\section{Broad sense P2P lending}

On the one hand, borrowers of $\mathrm{P} 2 \mathrm{P}$ lending could be companies. Peer-to-business (P2B) is a better description of this sense of $\mathrm{P} 2 \mathrm{P}$ lending (FCA, 2014). Borrowers are mainly middle and small enterprises, with the borrowing purpose of maintaining or expanding operations.
The borrowing amount is much larger than person-to-person lending.

On the other hand, lenders of P2P lending could be institutions. Some professional institutions use the own capital to purchase multi-platforms' multi-products and then transfer their creditor rights to more investors (Thomas, 2015).

\section{The definition of this research}

This research will adopt the broad sense of $\mathrm{P} 2 \mathrm{P}$ lending, considering all related modes as peerto-peer. It is due to the fact that there is few platforms in China belong to the field of pure person-to-person lending. Regulation is supposed to aim at the whole industry rather than only part of an industry. Therefore, if only narrow sense of P2P lending is studied, then the research on regulation will be meaningless.

\section{Status quo of P2P lending industry in China}

\section{Industry scale}

Since the first P2P lending platform Paipaidai was launched in 2007, China has experienced a slow increase in the first several years, with only 10 platforms and less than 15 million USD's trading volume in 2010 (WDZJ \& P2PEye, 2015). After that, China's P2P lending entered into a rapid growth period. Both platforms' amount and trading volume saw an explosive increase between 2011 and 2015. There were 2595 operating platforms at the end of 2015 , increasing $65 \%$ from 2014's 1575 platforms. The annually trading volume has grown by $288 \%$ from $\$ 37.95$ billion in 2014 to $\$ 147.3$ billion in 2015. In 2016, the amount of operating platform has a decreasing trend, while the trading volume is still expanding. Platforms' amount first presents a negative increase, as the regulatory strength is enhanced and unqualified platforms are ejected from the game with a higher speed.

According to University Cambridge's report on alternative finance (Cambridge, 2016), the US's P2P lending trading volume has achieved to $\$ 29.05$ billion in 2015 , which grew significantly by $232 \%$ from 2014's $\$ 8.76$ billion. For the UK, its market volume was up by $74 \%$ from $\$ 2.05$ billion in 2014 to $\$ 3.57$ billion in 2015. By contrast, China's $\$ 147.3$ billion trading volume in 2015 is 5 times and 41 times more than the US's and UK's separately. 
Yin, IJIBM, 2017; 1:4

Table 1. Asset side businesses in China's P2P lending

\begin{tabular}{|c|c|c|c|}
\hline & Asset type & Participating institutions & Typical platform \\
\hline \multirow{4}{*}{ Direct } & Credit loans & - $\quad$ P2P platforms & - $\quad$ Paipaidai \\
\hline & Credit loans + Risk reserve & - $\quad$ P2P platforms & - Yirendai \\
\hline & Guaranteed loans & $\begin{array}{l}\text { - } \quad \text { P2P platforms + guarantee companies } \\
\text { - } \quad \text { P2P platforms }\end{array}$ & $\begin{array}{l}\text { - Jimuhezi } \\
\text { - Weidai }\end{array}$ \\
\hline & Insurance loans & - $\quad \mathrm{P} 2 \mathrm{P}$ platforms + insurance companies & Lufax \\
\hline Indirect & Creditor rights & $\begin{array}{l}\text { - P2P platforms + small loans/ financial } \\
\text { leasing/factoring/ banks } \\
\text { - P2P platforms }\end{array}$ & Kaixindai \\
\hline
\end{tabular}

Figure 1. China's accumulative P2P lending platform amount

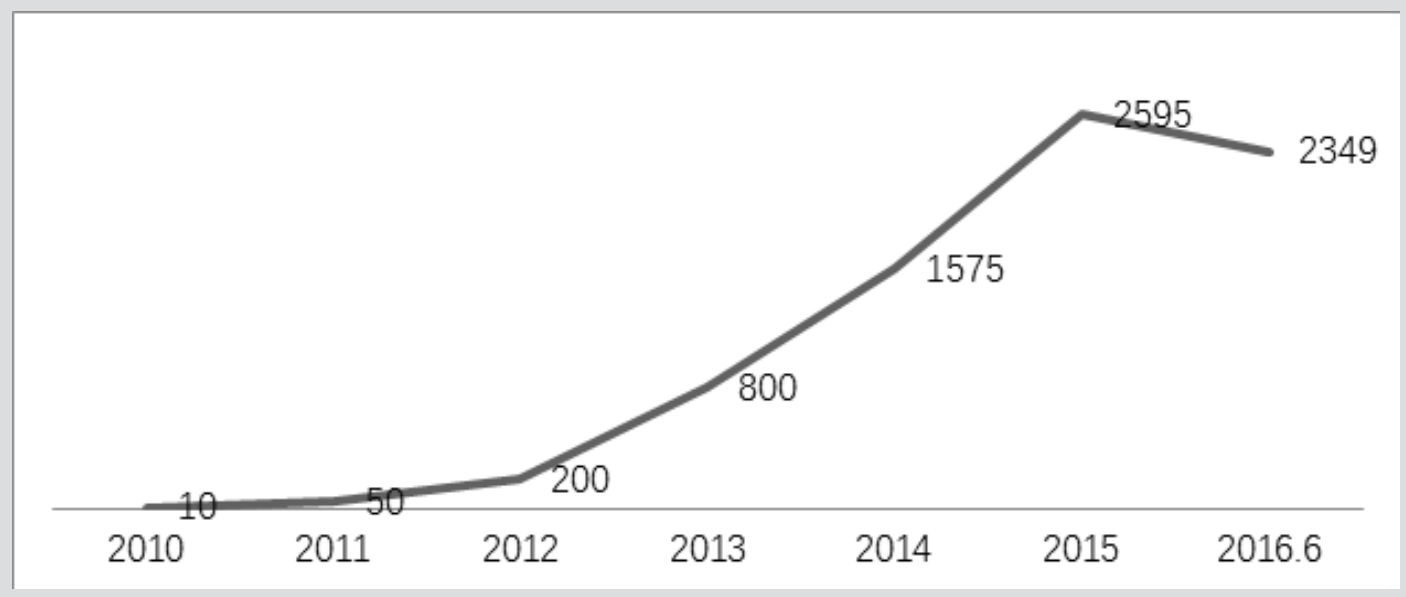

Source: WDZJ and P2PEye

Figure 2. China's P2P lending annually trading volume (Billion USD)

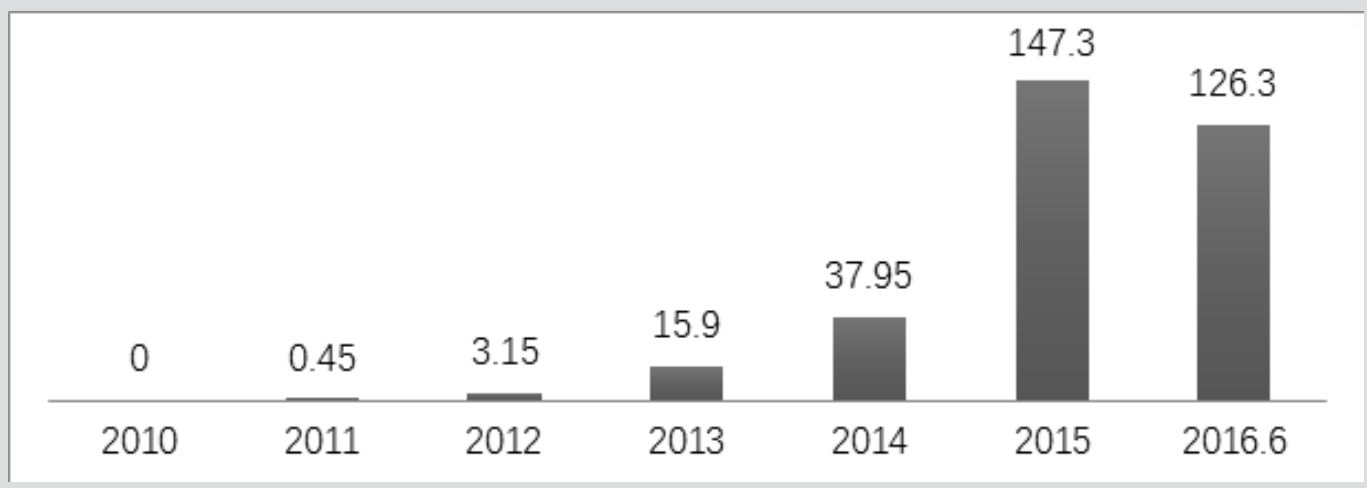

Source: WDZJ and P2PEye 
Along with the dramatic increase in trading volume, the amount of outstanding loan is also rising rapidly. The accumulative outstanding loan has achieved to $\$ 66$ billion in 2015 , increasing $323 \%$ from 2014's $\$ 15.6$ billion. The current amount at the end of June 2016 is $\$ 93.15$ CNY.

As for the amount of borrowers and lenders participating P2P lending market, the growth range is also significant. There were 2850 and 5860 thousand of borrowers and lenders in 2015, which were up by $352 \%$ and $405 \%$ from 2014's 630 and 1160 thousand respectively.

\section{Average maturity}

The average maturity of borrowing experienced a decrease from 6.9 months in 2011 to 4.73 months in 2013, and then an increase to 7.36 months in 2016. According to the monthly data from WDZJ, the term of borrowing tends to increase further.

\section{Average investment yield rate}

The investment yield rate saw a moderate growth from $18.9 \%$ in 2011 to $21.25 \%$ in 2013 , and then a constant decline to $11.38 \%$ in 2016 . In terms of the monthly data in 2016, the decreasing trend is really apparent. One reason is that more investors come into this market, exceeding the growth rate of borrowers. The imbalance between supply and demand results in the continuous decrease of investment yield rate. Another reason comes from the ease money market environment in China, as the central bank has cut interest rates and reserve ratios for several times in recent years (Bloomberg, 2015).

\section{Problem platforms}

Along with the explosive growth of P2P lending industry and the regulatory vacuum, problem platforms' eruption becomes a serious problem to China's P2P lending industry. The problem platforms' amount achieved to 896, increasing $226 \%$ from 2014's 275 platforms.

Among all the problem platforms in 2015, the largest proportion of $55 \%$ was due to platform runaway; $29 \%$ of platforms presented withdrawing difficulty; $15 \%$ was because of shutout, and $1 \%$ has been intervened by the police. Based on WDZJ's data (WDZJ, 2016), the percentage of problem platforms' vicious exit decreases from $85 \%$ in 2015 to $52 \%$ at the end of July 2016 .

To conclude, China's P2P lending market presents a trend of increasing scale and maturity while decreasing investment yield and problem platform amount, developing towards a reasonable and healthy direction.

\section{lending business models in China}

From analyzing the top $100 \mathrm{P} 2 \mathrm{P}$ lending platforms listed on WDZJ ranking in terms of the outstanding loan amount, all related businesses are summarized into three fields, the asset side, platform side, and liability side. From the perspective of $\mathrm{P} 2 \mathrm{P}$ lending platforms, assets are resources that will bring cash flows in the future. Therefore, asset side refers to borrowers' debt. Liabilities are on the opposite, thus refer to the lenders' creditor rights.

\section{Asset side}

In the narrow sense of P2P lending, borrowers are only individuals with small amount credit debt. But as the industry's dramatic growth, different kinds of borrowers and their debt emerge gradually. The consequence is that the asset side has tended to be diversified. Lingyi Academe published its research on China's P2P lending every year since 2013. Through these researches, we can see the development process of asset side in China's P2P lending industry.

P2P lending started from small amount unsecured loans for medium \& low-income individuals or small \& micro business owners. These are all people who are not serviced by traditional banks. As a result, P2P lending forms an important part of inclusive finance, receiving both borrowers and lenders' approval.

Along with the industry's development, more financing demand that was not serviced well by traditional banks also came out. Company borrowers started to occupy the main market share. At the same time, guaranteed loans gradually became the mainstream of $\mathrm{P} 2 \mathrm{P}$ lending in China. According to the Guaranty Law, main guarantee types include suretyship, mortgage, and pledge (NPC, 1995). Suretyship refers to a guarantor agrees to undertake the liability in case the borrower defaults, which is always from a third-party. Mortgage refers to borrowers secure loans 
Yin, IJIBM, 2017; 1:4

Figure 3. The US and UK's P2P lending trading volume (Billion USD)

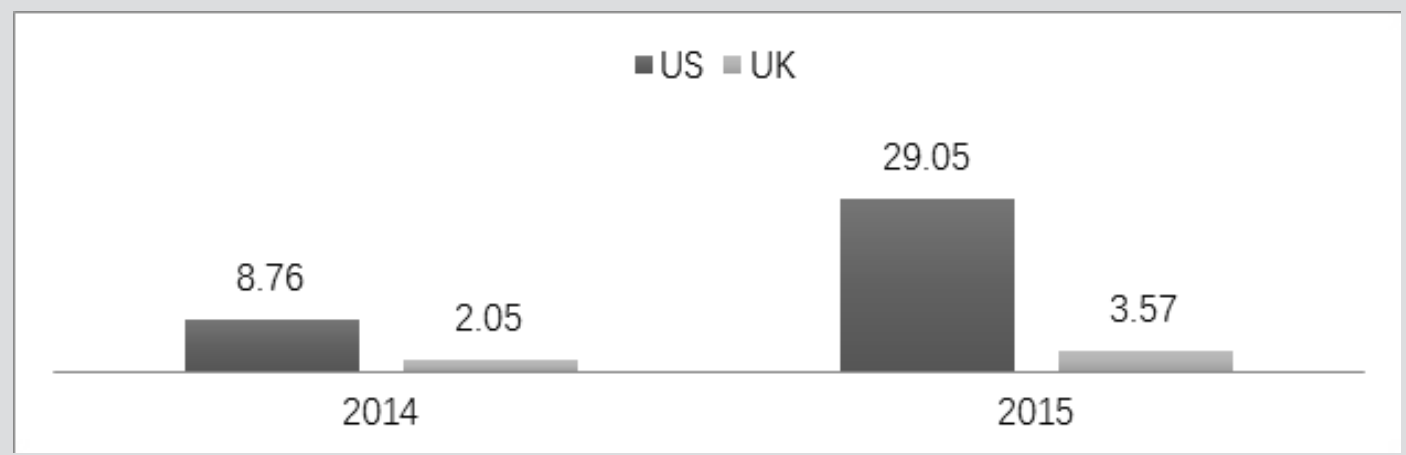

Source: University Cambridge

Figure 4. China's P2P lending accumulative outstanding loan amount (Billion USD)

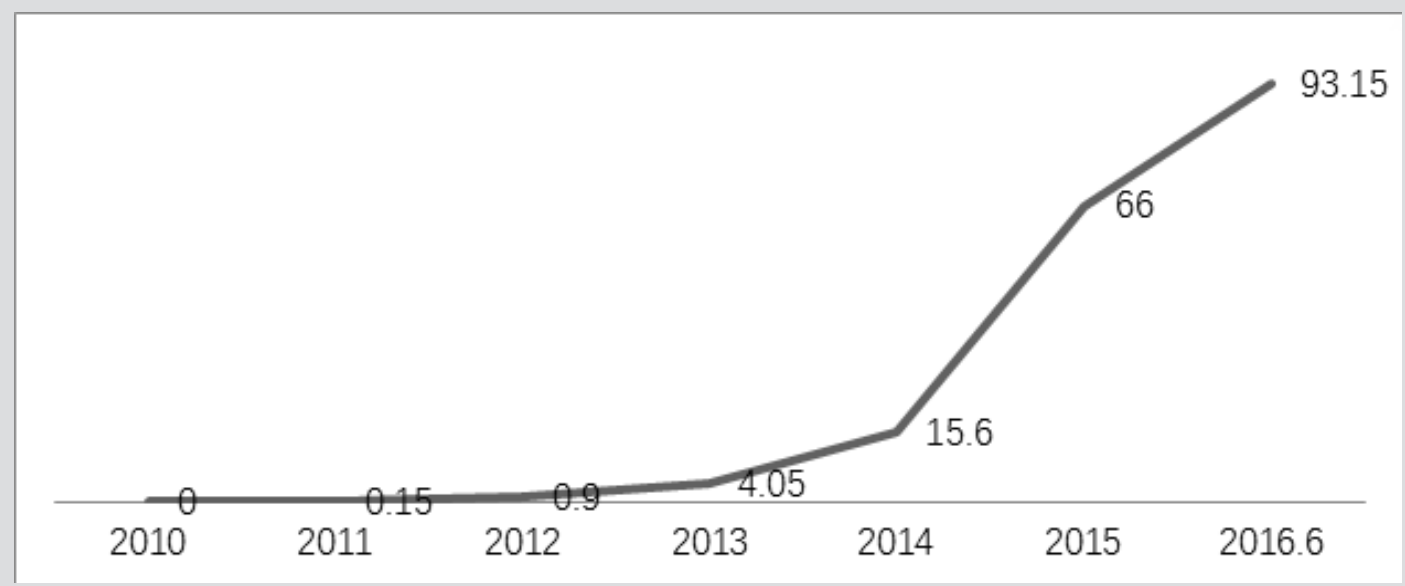

Source: WDZJ and P2PEye

Figure 5. China's P2P lending annually borrowers and lenders amount (Thousand people)

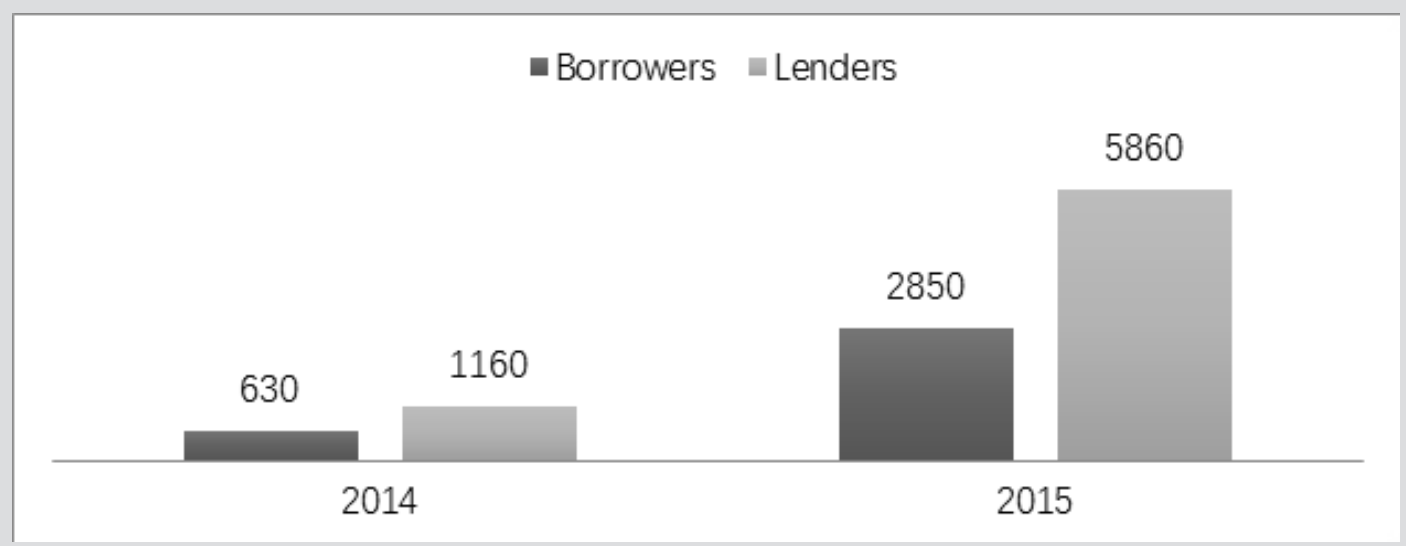

Source: WDZJ and P2PEye 
by providing collateral without transference of its possession, while pledge will transfer the possession of collateral to lenders. Both mortgage and pledge in P2P lending can be implemented by a third-party or platforms themselves. Mortgage properties are mainly real estates or cars, and pledge properties are mainly cars or acceptance bills.

After that, more professional assets were carried out. These are assets that need a higher level of professional abilities to manage (Lingyi, 2015), and are similar to securitization products. These assets always come from platforms' own or purchased creditor rights. Small loans companies, financial leasing companies, factoring companies, and banks' non-performing assets all have a high stress of economic capital and liquidity demand. They have strong motivation to move assets out of their financial statements. One way is to set up own $\mathrm{P} 2 \mathrm{P}$ lending platforms; the other is to cooperate with established P2P platforms.

After collecting and analyzing related information from 100 platforms' websites, this research divides the businesses on asset side into 5 types. The first 4 types are about loans, which are relatively direct compared with creditor rights. Paipaidai is the most typical platform that makes pure credit loans and not provides any risk protection to investors. By contrast, platforms like Yirendai have established the risk reserve fund to compensate investors when defaults happen. Jimuhezi and Weidai both focus on guaranteed loans, but the former cooperates with third-party guarantee companies while the latter implements guarantee process by itself. As guarantee companies are restricted by the leverage ratio requirement, they can only guarantee limited $\mathrm{P} 2 \mathrm{P}$ lending loans. At this time, insurance companies come into the P2P market and can solve that problem. Just like Lufax, who used to concentrate on guaranteed loans but is transferring its business to insurance loans gradually. Kaixindai is a typical platform that cooperates with financial institutions to transfer creditor rights.

Among 100 research sample platforms, $78 \%$ of platforms have a business of guaranteed loans, proving that the guarantee mode is a popular business model in China's P2P lending market.

\section{Platform side}

Platform side's businesses are divided into three parts according to the time order. They are before lending, during lending, and after lending period. The information below all comes from sample platforms' websites and is integrated by this paper.

\section{Before lending}

(1) Project review: in line with different platforms' specific assets, the review content and methods are also discrepant. Credit loan only refers to borrower's credit review. Guaranteed loan involves related review and assessment on guarantor or collateral. Additionally, review methods include the online, offline, and mixed review. Online review tends to use big data technology to implement credit rating (like Paipaidai), while the offline review is much more like traditional credit review method (like Weidai).

(2) Creditor rights purchase: platforms that have creditor rights from small loan companies or other financial institutions will also have this step to purchase the creditor rights. Or in practice, the purchase process could be replaced by another cooperation mode, which depends on the negotiation between two parties. The common purpose of different modes in this step is to put creditor rights that belonged to other institutions originally on P2P platforms to attract more investors and obtain more cash. In the sample platforms, Kaixindai has projects on small loans, banks, and insurance companies' creditor rights; while Dianrong focuses on factoring companies' projects.

(3) Pack loans or creditor rights: other than single projects, platforms also have products that include multi-projects. Among the 100 sample platforms, $65 \%$ of platforms has such packed projects. Platforms here will pack different projects into one new project, which looks like a kind of wealth management product. Diversification of single projects makes the package safer. Packages are more convenient for investors, as they do not have to select specific projects.

(4) Disclosure project information: after approving the loans or creditor rights, platforms will disclose related project information on their websites and wait for lenders' investment.

(5) Provide borrowing and investing channels: P2P lending platforms provide both borrowers and investors with online channels to operate the 
Figure 6. China's P2P lending average maturity (Months)

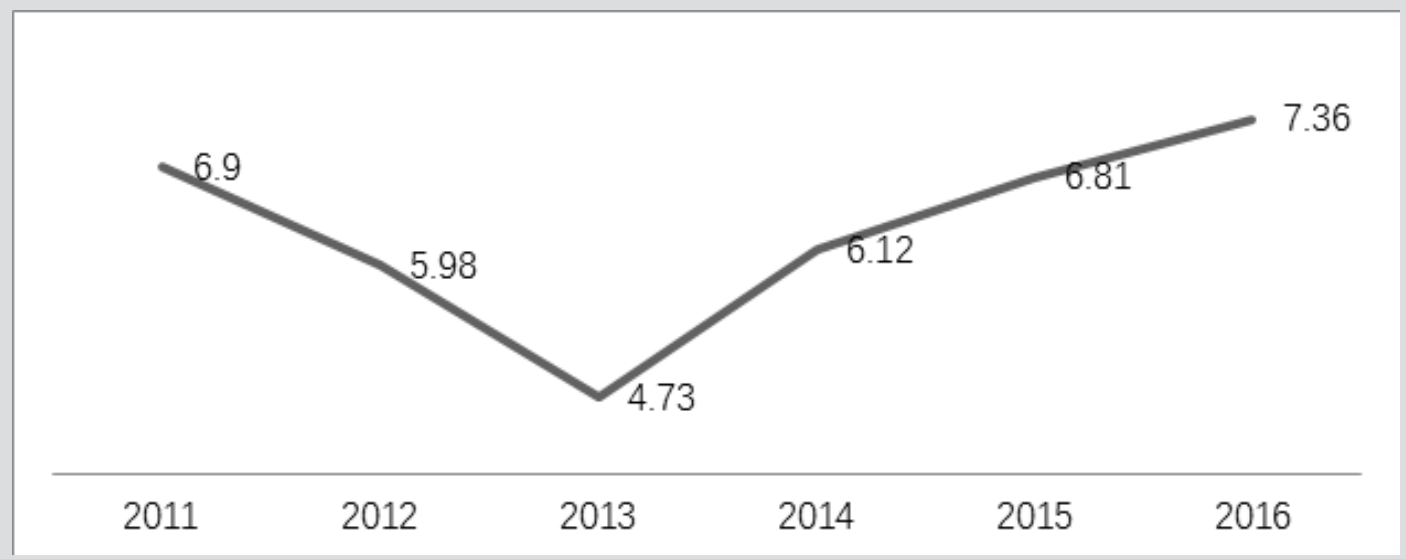

Source: WDZJ and P2PEye

Figure 7. China's P2P lending average maturity in 2016 (Months)

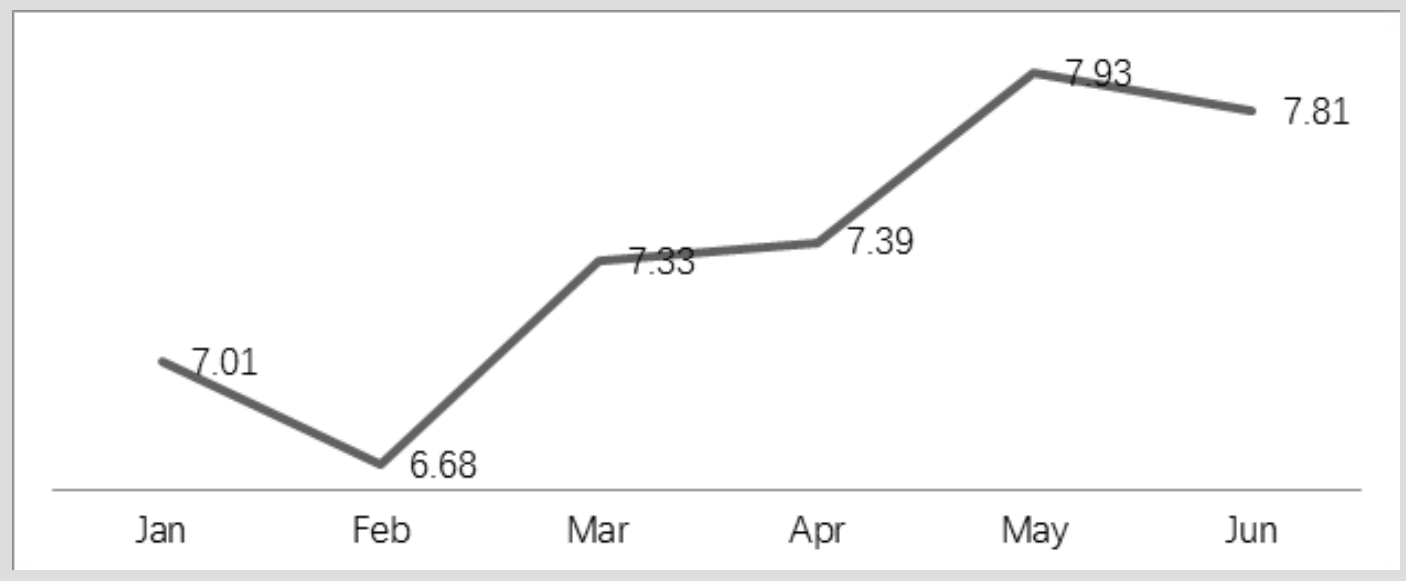

Source: WDZJ

Figure 8. China's P2P lending average investment yield rate

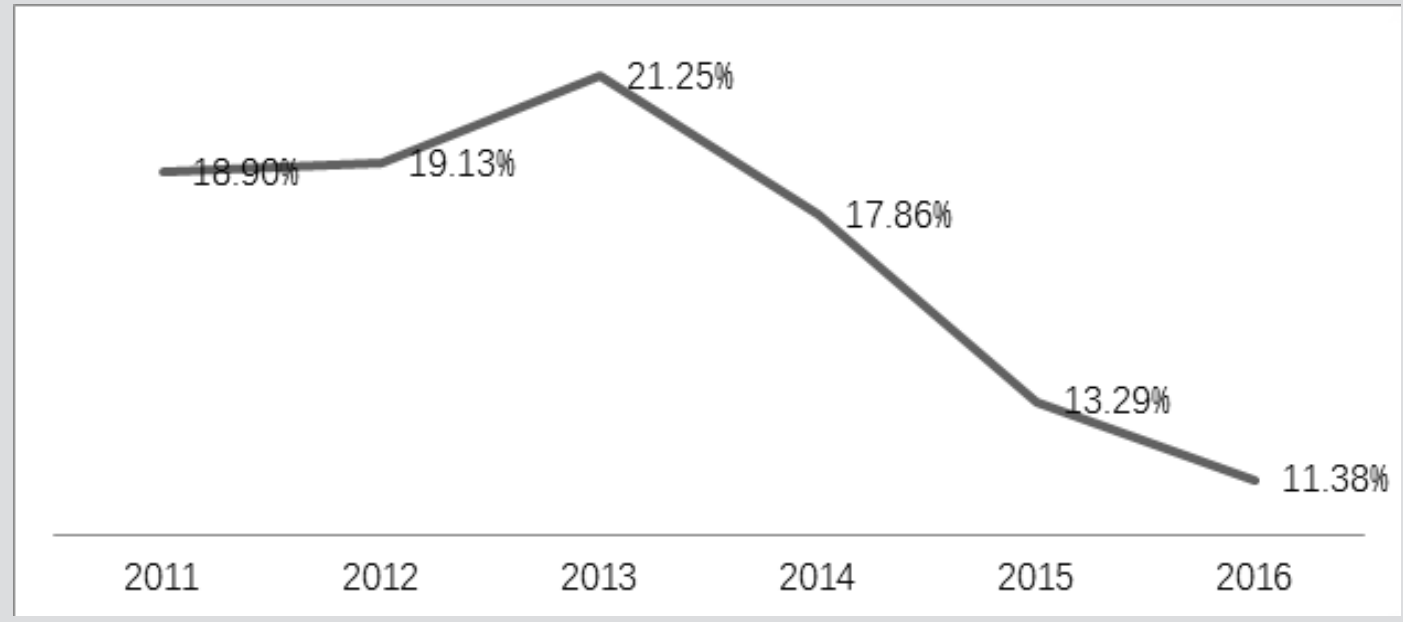

Source: WDZJ and P2PEye 
borrowing and lending process.

\section{During lending:}

(1) Constant tracking on projects: platforms will track on the use of loans lent to borrowers, ensuring the capital is allocated at the right place. Platforms should disclose timely information include the use of funds, borrowers' financial situation, borrowers' repayment ability changes and so on.

(2) Third-party custodian: to protect client money's security, platforms entrust third-party institutions like banks or third-party payment companies to monitor and manage the funds, ensuring lending capital is segregated from the platform.

(3) Repayment allocation: P2P lending platforms act as an intermediary to serve both borrowers and investors, allocating the principals and interests from borrowers to corresponding investors.

(4) Provide the secondary market for borrowing projects: some platforms provide investors with a secondary market to transfer their creditor rights. In our sample, $57 \%$ of platforms has such business. The liquid market gives original investors opportunities to exit the investments before maturity and gives other investors more investing choices.

\section{After lending:}

(1) Collect arrears: when non-performing loans come out, platforms have the responsibility to collect the money back.

(2) Guarantee process settlement: if the non-performing loans are guaranteed, platforms will implement related guaranteed processes. This step may refer to guarantor compensation or collateral treatment. After processing the related procedures, platforms are supposed to distribute the related income to investors.

(3) Risk reserve compensation: $59 \%$ of sample platforms have risk reserve mechanisms to protect lenders. If platforms provide risk reserve fund services, they will also withdraw money from the reserve fund and repay investors for the default loans.

\section{Liability side:}

Liability side refers to individuals or institutions with idle money and expect to obtain returns from online borrowing projects.

\section{Individuals}

P2P lending individual investors include people from all levels of net worth. Low-net-worth individuals can access to P2P lending market because the market has low thresholds. Highernet-worth individuals can invest in projects with higher thresholds and also safer characters. For example, Renrendai has both borrowing projects with thresholds of 100 CNY and 10,000 CNY.

\section{Institutions}

Financial institutions use professional analysis methods to choose high-quality P2P borrowing projects in different platforms and then pack the projects together to sell out as a P2P fund. High-quality selection and diversification investment make such P2P lending packages less risky. Touzhijia is a typical platform that launches P2P funds.

\section{Risks of P2P lending platforms}

Each kind of business will generate corresponding specific risks. These risks can be caused by P2P lending stakeholders' willingness or abilities. Willingness refers to defraud, while abilities relate to correlative financial and information technologies. In this part, the risks will also be analyzed from the perspectives of P2P lending's three fields, asset, platform, and liability side.

\section{Asset side}

\section{Moral hazard}

Borrowers may deliberately cheat money by providing fake information. After obtaining the capital, these borrowers will use the money to do other things rather than the original purposes when applying for the loans. Information fraud is a relatively easy thing under $\mathrm{P} 2 \mathrm{P}$ lending's current weak credit review environment.

\section{Credit risk}

The risk here mainly comes from borrowers' passive default rather than an active default in the above category. Borrowers may default because of several reasons. First, is the factor of a macroeconomic cycle, which may lead to individuals' unemployment and enterprises' bankruptcy. Next, is the factor from a micro level, which is quite different in each specific case. 


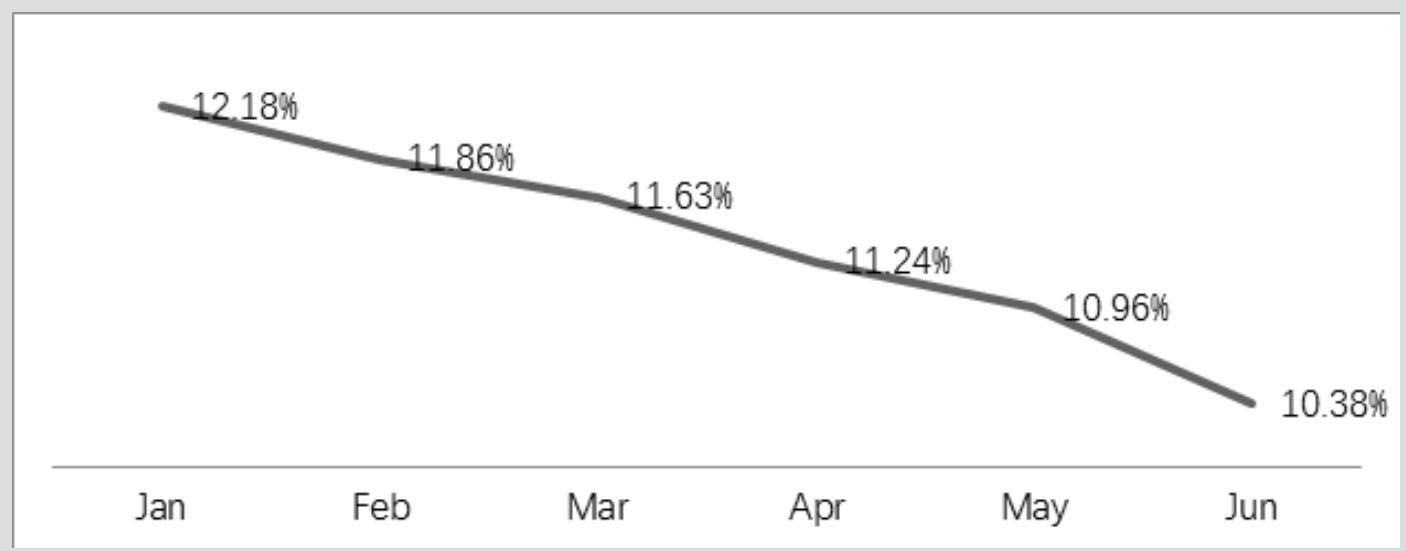

Source: WDZJ and P2PEye

Figure 10. China's P2P lending annually problem platform amount

\begin{tabular}{|c|c|c|c|c|c|}
\hline & & & \multirow[b]{2}{*}{275} & 896 & \multirow{2}{*}{515} \\
\hline & & & & & \\
\hline 10 & 6 & 76 & & & \\
\hline 2011 & 2012 & 2013 & 2014 & 2015 & 2016.6 \\
\hline
\end{tabular}

Source: WDZJ and P2PEye

Figure 11. China's P2P lending problem platforms by type in 2015

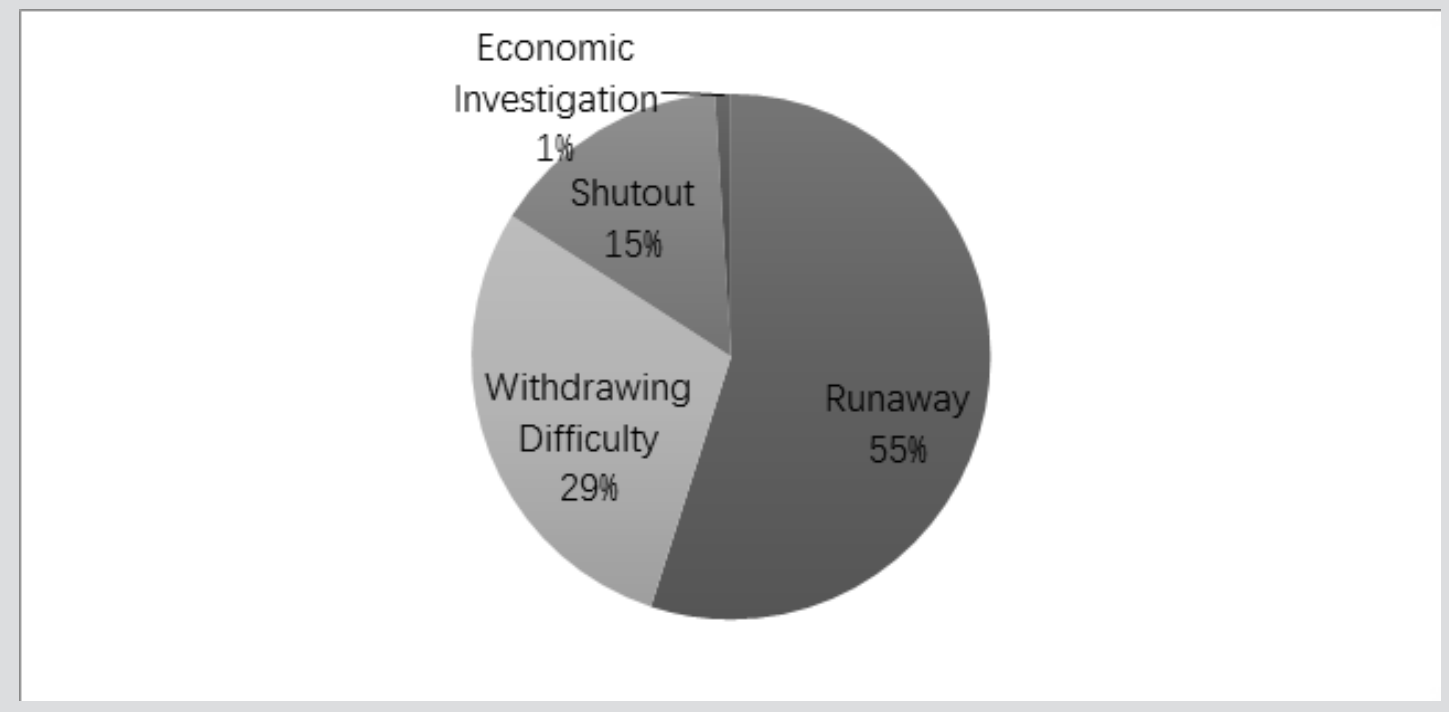

Source: WDZJ 


\section{Asset diversification risk}

Diversification of assets can effectively expand P2P lending market's scale, but at the same time brings more challenges. More types of assets increase P2P lending platforms' risk control pressure, as it means that platforms should adopt more measures to control corresponding risks. It needs platforms' professional abilities and more human input. Otherwise, diversification of assets will cause risk accumulation for platforms.

\section{Platform side}

\section{Moral hazard}

Platforms may issue fake projects to finance for themselves. After collecting investors' capital, the platform may use the money to meet its own funds demand rather than allocating to so-called borrowing projects. After that, the platform will use subsequent investors' money to repay the former investors' principals and interests. Some platforms may even run away directly after raising funds from investors. There also exists funds misappropriation risk from the fake third-party custodian. These platforms declare to entrust custodian banks or other institutions to monitor and manage client money, but actually, access to the funds freely and have the capital pool, providing convenient conditions to self-financing or runaway.

\section{Lack of credit investigation ability risk}

Each platform has its own credit review process and models when approving borrowing projects. However, there are vast differences in terms of their investigation abilities, as no technical thresholds are required to P2P lending platforms. Among the sample platforms, some platforms (like Lufax) have a background of traditional financial institutions, thus have experiences and abilities in credit review. But there are also some platforms that do not have such experiences before and have to explore in a new field.

\section{Operational risk}

Salesmen or credit review staff may unit potential borrowers to cheat platforms by using management or technology loopholes. For large projects, several credit investigation staff's joint fraud is another possibility. Huge platforms with a large amount of business and a large number of employees will be faced with more operation- al risk, which can exceed the credit review risk (Lingyi, 2015).

\section{Information disclosure risk}

As there are no unified standards on information disclosure in $\mathrm{P} 2 \mathrm{P}$ lending industry. Different platforms disclose different information in terms of the types, forms, and contents. Information disclosure refers to the contradiction between investors' interests safeguard and borrowers' privacy protection. Incomplete information disclosure can mislead investors, while excessive disclosure will leak borrowers' privacy.

\section{Liquidity risk}

Liquidity risk mainly comes from time mismatch between assets and liabilities. Some platforms split a long-term project into several short-term projects, attracting more investors and expanding the trading volume. When it comes to the maturity of the shorter-term project, platforms have the possibilities of not receiving back enough borrowing repayments to pay investors. Even worse, investors will get into a panic when they perceive withdraw difficulties and defund or choose not to invest on the platform, leading to more serious liquidity problems.

\section{IT risk}

Most P2P lending platforms' IT technology is not mature enough and far behind banks' systems. A large number of platforms' online systems are developed by small third-party companies (Lingyi, 2015). These systems have low costs, but also low security and stability. Weak online systems are more likely to be attacked or threatened by hackings.

\section{Credit risk}

Some platforms guarantee principals even interests without considering their real abilities as guarantors. Formal financing guarantee companies are restricted by requirements include leverage ratio limitations, while $\mathrm{P} 2 \mathrm{P}$ lending platforms always guarantee casually. When defaults really happen, those platforms without guarantee abilities will fail in performing their commitments to investors.

\section{Reputation risk}

When platforms are exposed to negative news, 
Figure 12. Sample platforms' asset situation

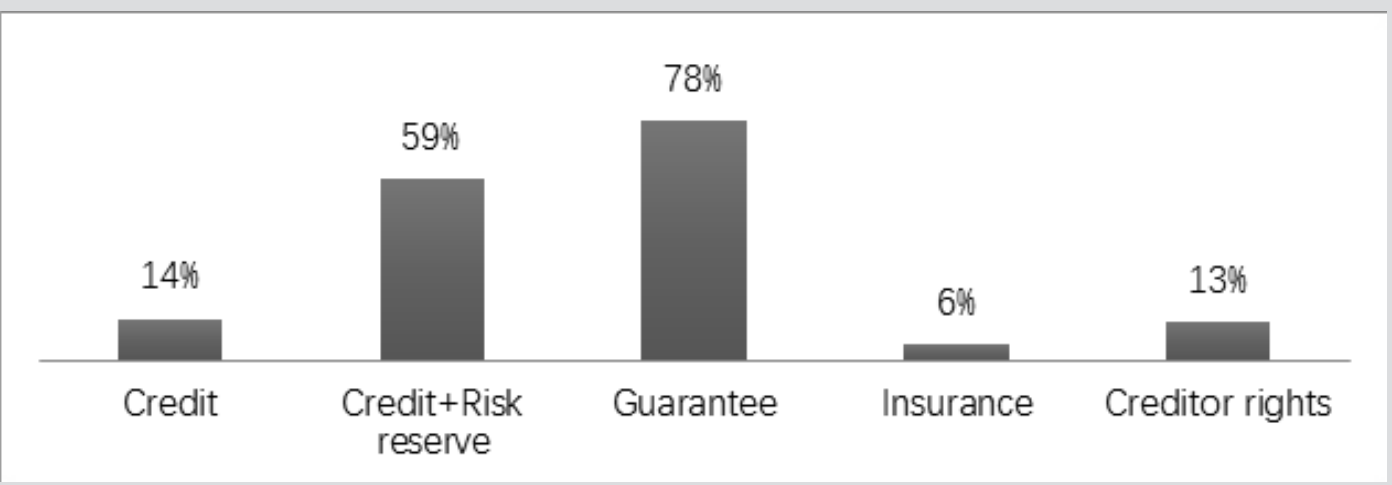

Figure 13. Platform side business in China's P2P lending

\begin{tabular}{|c|c|c|}
\hline Before lending & During lending & After lending \\
\hline Project review & Constant tracking & Arrears collection \\
\hline Creditor rights purchase & Third-party custodian & Guarantee settlement \\
\hline Projects package & Repayment allocation & \\
\hline Information disclosure & Secondary market & Risk reserve \\
\hline Lending channels & & \\
\hline
\end{tabular}

Figure 14. Asset side business and risk in China's P2P lending

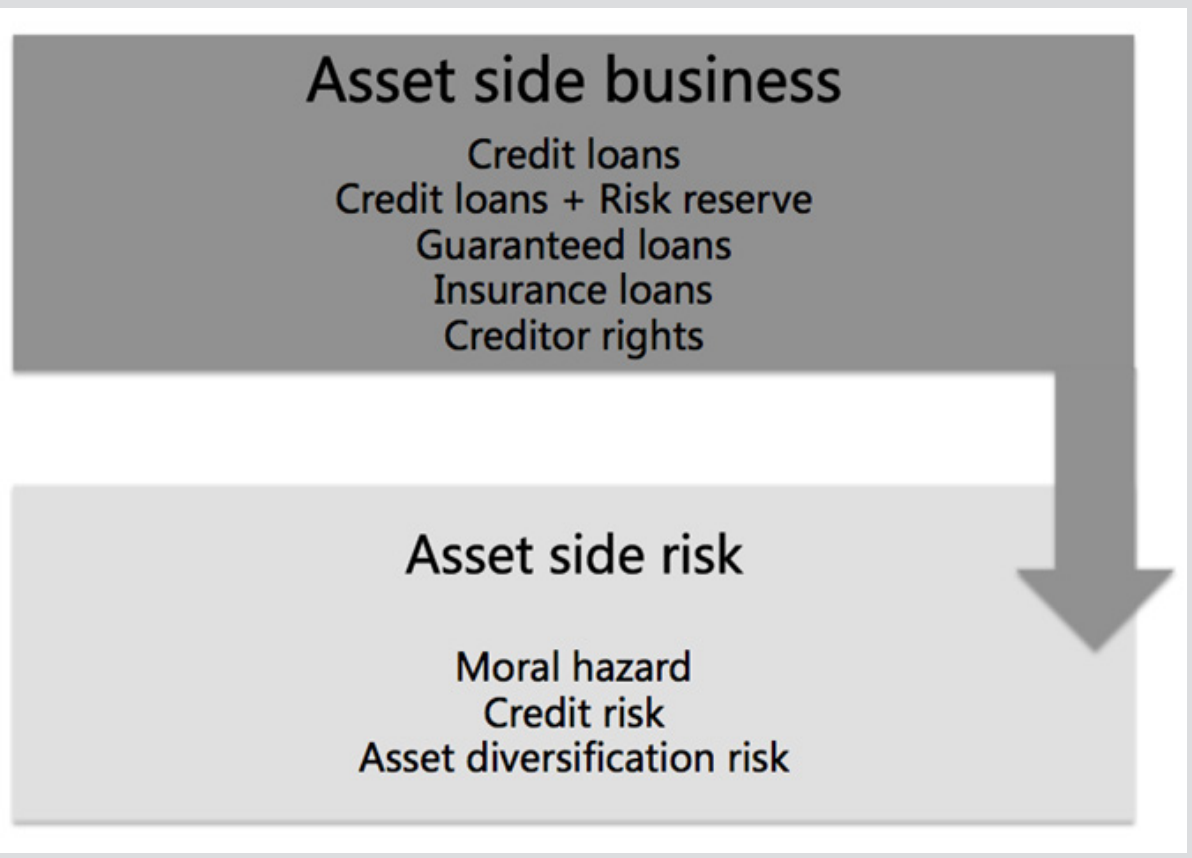


the reputation risk will emerge. Investors are very sensitive to negative news, as they have been frightened by over many problem platforms. Investors may lose confidence in and defund from the platforms, resulting in platforms' operating difficulties.

\section{Liability side}

\section{Lack of financial knowledge risk}

For a long time, Chinese debt market, especially local government financing platforms and state-owned enterprise bonds, are repaid in entrenched clauses (Reuters, 2014). Chinese investors are used to investing in an environment with rigid repayment schedules. As a result, most investors do not really care what type and amount of potential risks are with corresponding financial products but make decisions on if the principals and interests will be guaranteed. Rigid repayment investments make diversification and financial knowledge less meaningful, as investors will not lose no matter what products they purchase. For this reason, most investors lack necessary risk awareness and risk management skills. This investing inertia may be brought into P2P lending market by those investors, resulting in great losses.

\section{Moral hazard}

Compared with mutual funds, which have custodian banks to hold and safeguard the securities, P2P lending funds invested by institutional investors are not managed and monitored by banks or other financial institutions. Institutional investors have the possibilities to invest in unclear channels or even escape with the money funded from next level of investors.

\section{Lack of professional abilities risk}

At the present stage, there are no thresholds for P2P fund institutions enter into the market. Therefore, institutions' professional abilities range widely. Not all P2P fund institutions' investment decision models can stand the test.

\section{References}

Bloomberg. (2015). China Cuts Interest Rates as Policy Divergence With US Widens. Retrieved 22 July, 2016, from http://www.bloomberg.com/news/ articles/2015-10-23/china-cuts-interest-rates-reserve-ratios-to-counter-slowdown
Cambridge. (2016). THE 2015 UK ALTERNATIVE FINANCE INDUSTRY REPORT. Retrieved 23 July, 2016, from https://www.jbs.cam.ac.uk/fileadmin/ user_upload/research/centres/alternative-finance/ downloads/2015-uk-alternative-finance-industry-report.pdf

Cambridge. (2016). THE AMERICAS ALTERNATIVE FINANCE BENCHMARKING REPORT. Retrieved 23 July, 2016, from https://www.jbs.cam. ac.uk/fileadmin/user_upload/research/centres/alternative-finance/downloads/2016-americas-alternative-finance-benchmarking-report.pdf

FCA. (2014). The FCA's regulatory approach to crowdfunding over the internet, and the promotion of non-readily realisable securities by other media. Retrieved 21 July, 2016, from http://www.fca.org.uk/ static/documents/policy-statements/ps14-04.pdf

Lingyi. (2015). China's P2P lending service industry white paper. Beijing: Oriental Press.

NPC. (1995). Guaranty Law of the People's Republic of China. Retrieved 22 July, 2016, from http:// www.npc.gov.cn/englishnpc/Law/2007-12/12/content_1383719.htm

NPC. (1999). Contract Law of the People's Republic of China. Retrieved 23 July, 2016, from http:// www.npc.gov.cn/englishnpc/Law/2007-12/11/content_1383564.htm

NPC. (2004). Securities Law of the People's Republic of China. Retrieved 24 July, 2016, from http:// www.npc.gov.cn/englishnpc/Law/2007-12/11/content_1383569.htm

P2PEye. (2015). 2015 China's P2P lending industry annual report. Retrieved 21 July, 2016, from http:// www.p2peye.com/topic-nk2015.html

Reuters. (2014). UPDATE 1-In China, troubled shadow bank product tests no-default policy. Retrieved 22 July, 2016, from http://in.reuters.com/article/china-icbc-idINL3NOKQ2L520140116

Reuters. (2016). China police arrest 21 over $\$ 7.6$ bln online financial scam. Retrieved 21 July, 2016, from http://www.reuters.com/article/china-fraud-ezubao-arrest-idUSKCNOVA1E5

Slattery, P. (2013). Square pegs in a round hole: SEC regulation of online peer-to-peer lending and the CFPB alternative. Yale J. on Reg., 30, 233.

Thomas, Z. (2015). Institutional investors eye P2P lending platforms. International Financial Law Review, Retrieved from http://elib.tcd.ie/login?url=http:// search.proquest.com/docview/1697165553?accountid $=14404$

WDZJ. (2015). 2015 China's P2P lending industry 
annual report. Retrieved 21 July, 2016, from http:// wdzjosscdn.oss-cn-hangzhou.aliyuncs.com/nianbao/2015nianbao.pdf

WDZJ. (2016). 2016 China's P2P lending industry semiannual report. Retrieved 22 July, 2016, from http://www.wdzj.com/news/baogao/30277-all.html

WDZJ. (2016). P2P lending platform data. Retrieved 25 July, 2016, from http://shuju.wdzj.com/ platdata-1.html

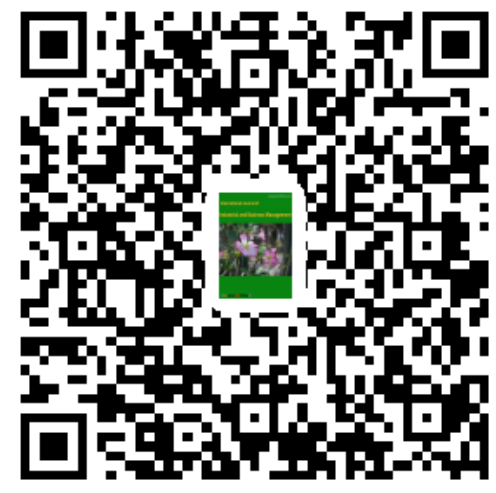

Figure 15. Platform side business and risk in China's P2P lending

\section{Platform side business}

Before lending

During lending

After lending

\section{Platform side risk}

Moral hazard

Credit review risk

Information disclosure risk

Operational risk

Liquidity risk

$$
\text { IT risk }
$$

Credit risk

Reputation risk

\section{Liability side business}

\section{Individuals}

Institutions

\section{Liability side risk}

\section{Lack of financial knowledge \\ Moral hazard \\ Lack of professional abilities}

